\title{
WODA JAKO PRZYCZYNA KONFLIKTÓW ZBROJNYCH W XXI WIEKU
}

\section{WATER AS THE CAUSE OF ARMED CONFLICTS IN THE 21ST CENTURY}

\author{
Paweł Borek $^{1(\mathrm{~A}, \mathrm{~B}, \mathrm{C}, \mathrm{D}, \mathrm{E}, \mathrm{F})}$
}

\author{
${ }^{1}$ Miejska Biblioteka Publiczna w Białej Podlaskiej
}

Borek, P. (2018). Woda jako przyczyna konfliktów zbrojnych w XXI wieku. Rozprawy Społeczne, 12(2), 32-37. https://doi.org/10.29316/rs.2018.11

\author{
Wkład autorów: \\ A. Zaplanowanie badań \\ B. Zebranie danych \\ C. Dane - analiza i statystyki \\ D. Interpretacja danych \\ E. Przygotowanie artykułu \\ F. Wyszukiwanie i analiza \\ literatury \\ G. Zebranie funduszy
}

Tabele: 0

Ryciny: 1

Literatura: 21

Otrzymano: maj 2017

Zaakceptowano: wrzesień 2017

\begin{abstract}
Streszczenie
Współczesna wojna o surowce ma charakter transgraniczny, zwłaszcza z powodu nieszczelności granic państwowych, a także wielorakości tego typu konfliktów. Główną przyczyną tego stanu rzeczy jest to, iż wpływ na wybuch i wzrost liczby konfliktów surowcowych ma stały wzrost zapotrzebowania na światowe zasoby naturalne. Ważną rolę w pojawianiu się sytuacji konfliktowych odgrywa fakt, że większość zasobów, na które istnieje podaż znajduje się na terenie krajów niestabilnych zarówno politycznie, jak i ekonomicznie. Woda jest podstawowym surowcem naturalnym, integralnym elementem wszystkich działań socjalnych i ekologicznych, służącym m.in. do produkcji energii, żywności, utrzymania zdrowia ludzkiego czy rozwoju przemysłowego. W dwudziestym pierwszym wieku systemy wodne i wodociągowe stają się coraz bardziej narażone na ataki podczas działań wojennych, jak również bycie przyczyną konfliktów zbrojnych w miarę wzrostu populacji ludzkiej. Nie mniej istotnym jest też fakt, że globalne zmiany klimatu powodują coraz większy popyt na wodę, co w niektórych regionach świata może stanowić zarzewie konfliktów.
\end{abstract}

Słowa kluczowe: woda, surowce naturalne, wojny i konflikty zbrojne, bezpieczeństwo międzynarodowe

\section{Summary}

The modern war for raw materials has a cross-border character, especially due to state borders being less than sealed tight, as well as due to the varied nature of such conflict types. The main cause of this state of affairs stems from the impact exerted on the outbreak and proliferation of resource-related conflicts by a steadily increasing worldwide demand for natural resources. An important role in the emergence of conflict situations is played by the fact that most of the resources which are on offer can be found in both politically and economically unstable countries. Water is a basic natural resource, an integral element of all social and ecological activities, used, among others, for the production of energy, food, maintaining human health or industrial development. In the twenty-first century, water systems and water supply systems are becoming increasingly vulnerable to attacks during hostilities, as well as prone to causing armed conflicts with the rising population figures. The fact that global climate change brings about an increasing demand for water, sparking off conflicts in some regions of the world, is no less important.

Keywords: water, natural resources, wars and armed conflicts, international security
Jeśli wojny tego wieku toczyły się o ropę, to wojny następnego stulecia będą toczyły się o wodę.

Ismail Serageldin

\section{Wprowadzenie}

W teorii stosunków międzynarodowych wypracowano dwie koncepcje wojen o surowce naturalne. Pierwszą z nich są tzw. stare wojny o podłożu geopolitycznym, które najczęściej toczyły się między światowymi potęgami, lub organizmami państwowymi, aspirującymi do miana suwerennych aktorów międzynarodowych. Drugą koncepcją są tzw. nowe wojny, toczone przez organizmy niepaństwo- we, głównie bojówki zbrojne lub grupy rebelianckie. $\mathrm{Z}$ powodu rozpadu centralnej władzy państwowej, organizacje zbrojne stanowią w rzeczywistości jedyną siłę na obszarze przez siebie kontrolowanym. Współczesne wojny surowcowe najczęściej mają charakter transgraniczny, zwłaszcza ze względu na nieszczelność granic państwowych i wielowymiarowość konfliktów. Częste są więc interwencje państw trzecich w antagonizmy wewnętrzne innego państwa, czy to za pomocą profesjonalnej armii, czy też z użyciem wspieranych finansowo i politycznie bojówek zbrojnych (Borek, 2014).

Głównym czynnikiem, który ma wpływ na powstawanie i wzrost liczby konfliktów surowcowych jest stałe zwiększanie się popytu na surowce natu-

Adres korespondencyjny: Paweł Borek, Miejska Biblioteka Publiczna w Białej Podlaskiej, ul. Warszawska 12a, 21-500 Biała Podlaska, e-mail: pawel.borek@mbp. org.pl, tel.: 833416454

Copyright by: Państwowa Szkoła Wyższa im. Papieża Jana Pawła II w Białej Podlaskiej, Paweł Borek

Czasopismo Open Access, wszystkie artykuły udostępniane są na mocy licencji Creative Commons Uznanie autorstwa-użycie niekomercyjne-na tych samych warunkach 4.0 Międzynarodowe (CC BY-NC-SA 4.0, http://creativecommons.org/licenses/by-nc-sa/4.0/). 
ralne w skali światowej. Dużą rolę w powstawaniu sytuacji konfliktowych odgrywa też fakt, że większość surowców od których dostaw uzależnionych jest wiele państw, położona jest w krajach niestabilnych zarówno politycznie, jak i gospodarczo.

Biorąc pod uwage podstawowe potrzeby egzystencjonalne człowieka woda oraz swobodny dostęp do niej jest fundamentalny. Woda była, jest i będzie potrzebna człowiekowi zawsze, dlatego też była ona pierwszym surowcem naturalnym, o który zaczęto toczyć zażarte walki. W ten sposób właśnie woda wpisała się zarówno w historię, jak i najprawdopodobniej przyszłość konfliktów zbrojnych. Poza tym woda ma bezapelacyjnie specjalny status wśród reszty surowców energetycznych i mineralnych, które mają swoje substytuty, natomiast wody nie można niczym zastąpić (Gleick, 1993). Co za tym idzie świadomość wzrostu zapotrzebowania na wodę w skali globalnej, przy w miarę jej stałej ilości w naturalnym środowisku, budzi często większe zaniepokojenie, niż perspektywa braku innych surowców naturalnych ${ }^{1}$.

Ponadto zasoby wody na świecie są nierówno rozmieszczone zarówno na całym globie, jak i w poszczególnych regionach, większość zaś rzek ma transgraniczny charakter. Woda pitna nie może być tanio transportowana w dużych ilościach na znaczne odległości, natomiast kontrola biegu rzek w postaci budowy hydroelektrowni może zapewnić energię tym krajom, które mają ograniczony dostęp do innych surowców naturalnych (ropy naftowej, węgla, etc.) (Piotrowski, 2005).

\section{Woda jako przyczyna konfliktów zbrojnych}

Wojny, których rzeczywistą przyczyną jest rywalizacja o wodę, często są przedstawiane jako konflikty etniczne lub wojny religijne. Takim przykładem był konflikt w Pendżabie (Indie) w latach 80. XX wieku, kiedy spór o podział wód rzecznych na arenie międzynarodowej został przedstawiony jako problem separatyzmu sikhijskiego. Podobnie konflikty izraelsko-arabskie bardzo często są postrzegane tylko przez pryzmat rywalizacji o terytorium i konfliktu między wyznawcami judaizmu i islamu. Motyw rywalizacji o swobodny dostęp do wody jest albo zupełnie pomijany, albo co najwyżej traktowany marginalnie (Lipowska-Hamdy, 2016).

W ciaggu ostatniego półwiecza znacznie wzrosło globalne zapotrzebowanie na wodę. Jedną z głównych przyczyn tego stanu rzeczy jest wzrost populacji państw tzw. Globalnego Południa oraz częste okresy suszy związane ze zmianami klimatycznymi. Liczba ludności na świecie wzrosła z $3038 \mathrm{mi}-$ liarda w 1960 roku do 6895 miliarda w 2010 roku. Przewiduje się, iż do 2050 roku wzrośnie ona do 9 miliardów. Szybko postępuje także zapotrzebowanie na wodę w gospodarstwach domowych i przemyśle, zwłaszcza w dużych ośrodkach miejskich.

\footnotetext{
${ }^{1}$ Woda pitna stanowi tylko 3\% światowych zasobów, gdyż pozostałe 97\% stanowią morza i oceany.
}

Wiele państw półkuli południowej nie jest w stanie wyżywić swoich mieszkańców, a co za tym idzie żeby zapobiec głodowi - kraje te biorą udział w projektach rozwoju rolnictwa powodujących ubytek wody w krajach ościennych. Prowadzi to jednak do konfliktów międzynarodowych (Lipowska-Hamdy, 2016).

Minimalne zapotrzebowanie na wodę dla człowieka wynosi 20 litrów dziennie. Jednak miliard osób na Ziemi do zużycia posiada zaledwie 5 litrów dziennie. Najsilniej deficyt wody odczuwany jest obecnie na Bliskim Wschodzie, w krajach Afryki Środkowej i Wschodniej, Indiach oraz Azji Środkowej. Współcześnie niedobór wody odczuwa około 700 milionów ludzi w 43 krajach, zaś do 2025 roku z powodu globalnych zmian klimatu i wzrostu światowej populacji liczba ta przekroczy trzy miliardy (Kałmykowa, 2016).

Obecnie na świecie bardzo łatwo można znaleźć regiony, gdzie swobodny dostęp do wody pitnej staje się problemem społeczno-politycznym, prowadząc często do konfliktów i napięć. Analiza czynników określających podatność danego kraju na niedobór wody świadczy o tym, że ilość takich miejsc ciągle rośnie. Dotyczy to zwłaszcza stosunku popytu do podaży, konkurencyjnych interesów państw leżących blisko jednego zbiornika wodnego oraz dostępności wody w przeliczeniu na jednego mieszkańca (Piotrowski, 2005).

Prawdopodobieństwo konfliktu pojawia się zwłaszcza tam, gdzie woda jest surowcem deficytowym, a zapotrzebowanie na nią jest bardzo duże. Problem ten dotyczy więc krajów z ubogą siecią hydrograficzną oraz znajdujących się w strefach małych opadów atmosferycznych. Biorąc za punkt odniesienia ilość wody przypadającą na jednego mieszkańca w skali roku, uznaje się, że w państwach, w których wynosi ona poniżej $1000 \mathrm{~m}^{3}$, występuje niedobór wody, natomiast gdy wskaźnik ten wynosi poniżej $500 \mathrm{~m}^{3}$ oznacza jej brak, powodujący zagrożenie dla ludzkiego życia² ${ }^{2}$. Ograniczony dostęp do źródeł wody pitnej, który zgodnie z szacunkami WHO dotyczy obecnie blisko 1,1 mld ludzi, staje się więc głównym czynnikiem prowadzącym do konfliktów i napięć społecznych (Hoffman, 2016).

Konflikty te mają najczęściej charakter wewnętrzny, jednakże w niedalekiej przyszłości walki o wodę coraz częściej moga toczyć się na arenie międzynarodowej, zwłaszcza tam, gdzie nieliczne, a często także jedyne znaczące $w$ danym regionie rzeki, jeziora, czy wody gruntowe - są dzielone pomiędzy dwa lub więcej państw. Podatność danego kraju na uczestnictwo w tego typu konfliktach zależeć będzie m.in. od: stopnia niedoboru wody

\footnotetext{
${ }^{2}$ Zgodnie z klasyfikacją Banku Światowego państwa, w których roczna ilość wody przypadająca na jednego mieszkańca utrzymuje się na poziomie poniżej $1000 \mathrm{~m}^{3}$, to m.in.: Algieria, Arabia Saudyjska, Egipt, Izrael, Jordania, Jemen, Libia, Maroko, Malezja, Syria, Tunezja oraz Zjednoczone Emiraty Arabskie. Zob. szerzej: From Scarcity to Security: Averting a Water Crisis in the Middle East and North Africa (1995), World Bank Washington DC, s. 6-7.
} 


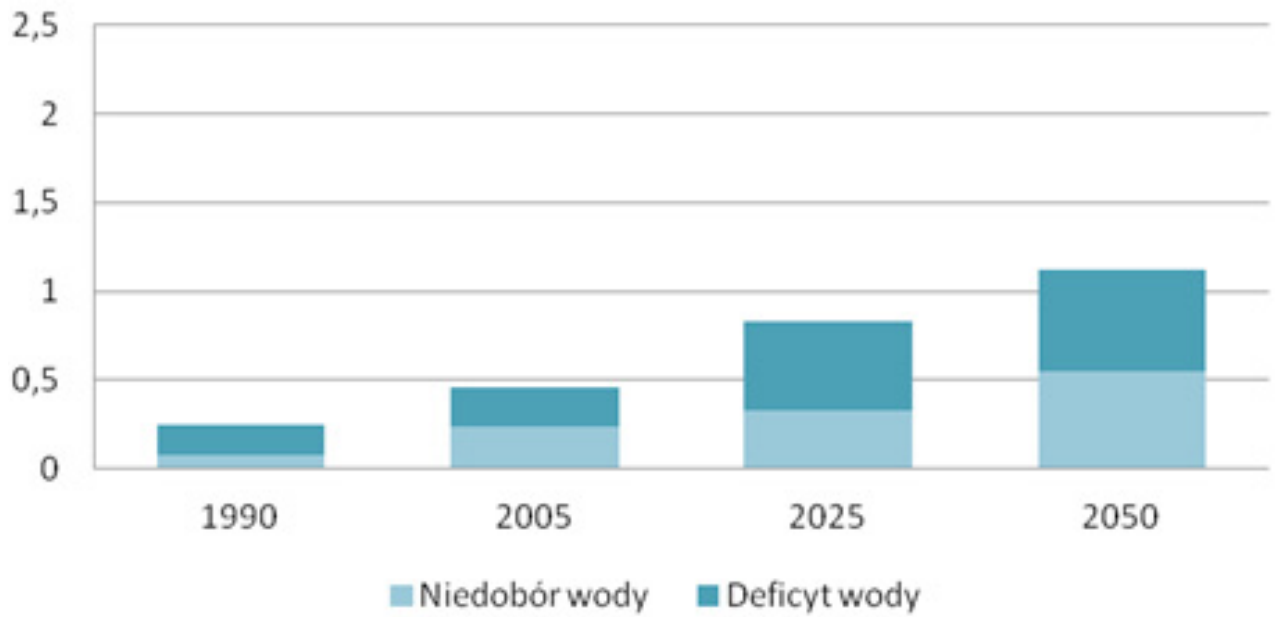

Rycina 1. Ludność doświadczająca deficytu i niedoboru wody w państwach arabskich podana w miliardach osób Źródło: Lipowska-Hamdy, 2016.

w regionie, znaczenia i wartości zbiornika wodnego dla danego państwa, zasięgu, w jakim zasoby wodne dzielone są pomiędzy kilka państw, czy wreszcie dostępności alternatywnych źródeł wody pitnej (Klare, 2002; Gleick, 1993). Takimi zapalnymi regionami, gdzie przepływająca przez terytorium kilku krajów rzeka jest źródłem konfliktów, są dorzecza Nilu, Tygrysu i Eufratu, Jordanu, dorzecza Indusu, Amu-darii i Syr-darii, Kolorado, Dunaju, Kongo, Nigru, Okavango, i Senegalu.

\section{Konflikty o wodę w Afryce i na Bliskim Wscho- dzie}

Wraz z dekolonizacją Afryki rzeka Nil zaczęła skupiać uwagę badaczy jako potencjalne źródło konfliktów. Ta najdłuższa rzeka świata przepływa przez terytoria 10 państw, z których aż 9 (Burundi, Demokratyczna Republika Konga, Erytrea, Etiopia, Kenia, Ruanda, Sudan, Tanzania, Uganda) należy do światowej czołówki słabo rozwiniętych i najbiedniejszych państw świata. Sa to regiony destabilizacji politycznej, ruiny gospodarczej oraz wielu innych społecznych problemów, które w znacznym stopniu są konsekwencją wyniszczających, wieloletnich wojen domowych (Lipowska-Hamdy, 2016).

Dziesiątym krajem, położonym u ujścia Nilu, jest Egipt - militarna i gospodarcza potęga w tym regionie. Historycznie państwo to kształtowało się w dolinie Nilu, i cała jego historia związana jest z wodami tej rzeki. Dla Egiptu, którego terytorium w 98\% stanowi pustynia, kontrola górnych wód - Nilu Białego i Nilu Błękitnego, polegająca głównie na niedopuszczaniu do samowolnego budowania przez państwa Afryki Środkowej i Północnej zapór wodnych oraz innych konstrukcji modyfikujących naturalny bieg rzeki, stała się kwestią o najwyższym priorytecie w jego polityce bezpieczeństwa. Problem ten nabrał szczególnego znaczenia wraz z powstaniem nowych, niepodległych państw w tym regionie, które zaczęły domagać się respektowania swoich su- werennych praw w zakresie kontroli i eksploatacji zasobów wodnych, znajdujących się na ich terytorium (Williams, 2002).

Wobec jednego z największych w skali światowej wzrostu demograficznego, którego doświadczają wszystkie kraje dorzecza Nilu, każdemu z nich zależy na zwiększaniu poboru wody z tej rzeki. W najlepszej sytuacji są państwa leżące w górnym odcinku Nilu, zwłaszcza Etiopia, kontrolująca blisko 85\% jego potencjału wodnego. Każdy projekt podejmowany przez sąsiadów Egiptu, naruszajacy naturalny bieg rzeki oraz zmierzający jednocześnie do uszczuplenia jego zasobów wodnych, spotyka się ze zdecydowanym sprzeciwem tego kraju. Wielu egipskich polityków zdaje się potwierdzać, że głównym czynnikiem konfliktogennym w regionie zaczyna być właśnie woda. Po zawarciu pokoju z Izraelem w 1978 roku prezydent Anwar Sadat deklarował, że jedynie woda może pchnąć Egipt ku wojnie. Z kolei Boutros Boutros-Ghali, jeszcze jako egipski minister, ostrzegał w latach 70. XX wieku, że następna wojna w regionie rozegra się o nie politykę, lecz o wodę (Pronińska, 2005).

W kontekście konfliktów zbrojnych o wodę, szczególną uwagę należy zwrócić na Bliski Wschód. System rzeczny Jordanu, obejmujący obecnie terytoria Izraela, Autonomii Palestyńskiej, Jordanii, Syrii i Libanu, już od starożytności był przedmiotem rywalizacji Zydów i ludów zamieszkujących dolinę rzeki. Także obecnie Jordan staje się źródłem konfliktów, które są zarazem jednym z aspektów rywalizacji arabsko-izraelskiej w tym regionie (http:// www.national-geographic.pl/ludzie/wojny-o-wode). Postrzeganie dostępu do rzeki Jordan jako kwestii życia lub śmierci narodu, jest szczególnie widoczne w wypowiedziach polityków izraelskich, m.in. byłego premiera Mosze Szaretta, który określił wodę jako „życie samo w sobie dla Izraela” (Pronińska, 2005).

Za dążeniem do uzyskania jak największego udziału w wykorzystaniu wód Jordanu przemawia wiele argumentów, z których najważniejszym jest 
fakt, iż w większości krajów doliny Jordanu (Izrael, Jordania, Syria) ilość wody przypadająca na jednego mieszkańca utrzymuje się na poziomie poniżej 1000 $\mathrm{m}^{3}$ rocznie. Trzeba przy tym pamiętać, że Jordan nie jest rzeką o zbyt dużym potencjale. Projekty wodne wdrażane niezależnie zarówno przez Izrael, jak i kraje arabskie były w przeszłości przyczyną dodatkowych napięć (w i tak już wrogich) wzajemnych stosunkach. Przykładowo w 1960 r. kraje arabskie, chcąc zablokować realizację izraelskiego projektu NWC (National Water Carrier), zdecydowały o zamknięciu tam na rzekach Hasbani i Baniyas zasilających Jordan $260 \mathrm{mln} \mathrm{m}^{3}$ wody rocznie. Uznając te działania za wrogi akt wymierzony w „źródło życia" narodu żydowskiego Izrael zagroził zastosowaniem wszelkich koniecznych środków do zapewnienia niezakłóconego biegu rzeki (Rękawek, 2016). W latach 60. XX wieku doszło także do kilku poważnych incydentów zbrojnych: poczynając od izraelskich nalotów powietrznych, celem których było zniszczenie infrastruktury rzecznej Syrii, poprzez wojnę sześciodniową w 1967 r., w której Izrael znacząco zwiększył swoją przewagę strategiczną w dolinie Jordanu, uzyskując kontrolę m.in. nad rzeką Baniyas, po późniejsze ataki zbrojne przeprowadzane przez Organizację Wyzwolenia Palestyny na izraelskie instalacje wodne, na które w odpowiedzi Izrael uderzył kolejny raz w infrastrukturę rzeczną swoich sąsiadów (Jokiel, 2016) ${ }^{3}$. Najważniejszymi cechami charakterystycznymi dla tego konfliktu są: duży przyrost naturalny ludności; mocno zanieczyszczone wody gruntowe i powierzchniowe, konflikt o podłożu religijnym, okresy dotkliwych susz oraz działalność terrorystyczna (Pawłowski, 2016).

Pomimo zawarcia przez Izrael w latach 90. XX w. porozumień z Jordanią i OWP $\mathrm{w}$ zakresie regulacji stosunków wodnych groźba wybuchu konfliktu o wodę $w$ omawianym regionie wciąż pozostaje realna. Wzrost demograficzny, niewystarczająca ilość dostępnej wody pitnej w regionie, utrzymujące się antagonizmy $w$ innych kwestiach i niechęć do opracowania wspólnej, regionalnej strategii sprawiedliwego rozdziału wód Jordanu mogą w niedalekiej przyszłości sprowokować poważny konflikt (Rękawek, 2016).

Nie można jednak pominać okresów wspólnego działania między zwaśnionymi stronami. Syria rozwija współpracę z Izraelem w dziedzinie retencjonowania wody, Jordania natomiast podpisała z nim umowę, stanowiącą, że w razie długich okresów suszy będą podejmowane wspólne działania w celu przezwyciężenia jej skutków (Lipowska-Hamdy, 2016).

Jak zauważa Marina Sapronowa: „Jordan, podobnie jak jego dopływy, jest podstawowym źródłem wody dla całego Bliskiego Wschodu. Dlate-

\footnotetext{
${ }^{3} \mathrm{Z}$ tego powodu w 1969 r. wojska Izraela przeprowadziły serię ataków na system Kanału Wschodniego Ghor, które doprowadziły do zniszczenia systemu nawodnień Jordanii. Po tych wydarzeniach, król tego kraju nia systemu nawodnień Jordanii. Po tych wydarzeniach, król tego kraju
- Husajn, zgodził się doprowadzić do zaprzestania wspierania działalności OWP w Jordanii, Izrael natomiast zapewnił, że po odbudowie kanału nie stanie się on na nowo celem ataków z jego strony.
}

go ta kwestia odgrywa ważną rolę w stosunkach jordańsko-syryjskich, jordańsko-izraelskich, syryjsko-irackich, libańsko-izraelskich, palestyńsko-izraelskich. Wszystkie państwa, które pobierają wodę z jednego źródła, napotykają na sytuacje konfliktowe w stosunkach z sąsiadami. Jednak jedynie Jordania utrzymuje stosunki dyplomatyczne z Izraelem. Dlatego problem tkwi w braku możliwości uregulowania kwestii wodnej na szczeblu stosunków dwustronnych między różnymi krajami" (Kowalenko, 2016).

Obszarem szczególnie podatnym i zagrożonym wybuchem konfliktu o wodę jest Strefa Gazy. Niedobór wody, jakiego doświadczają tamtejsi Palestyńczycy, już teraz wywołuje konflikty społeczno-polityczne. Jego głównymi przyczynami są: spadek ilości dostarczanej wody, wzrastający popyt na wodę, spowodowany nadmierną eksploatacją zbiorników wodnych i ich degradacja, oraz wprowadzone przez Izrael regulacje w zakresie uży tkowania przez Palestyńczyków i ilości dostarczanej im wody pitnej. Często regulacja stosunków wodnych uznawana jest za kluczowy problem zarówno jeżeli chodzi o kształtowanie się przyszłych stosunków izraelsko-palestyńskich, jak też rozwój procesu pokojowego na Bliskim Wschodzie (Lipowska-Hamdy, 2016) ${ }^{4}$. Współpraca w zakresie hydrotechnologii między Izraelem a Palestyną przyniosłaby więc znaczny spadek napięcia pomiędzy obiema społecznościami, w efekcie czego mogłaby doprowadzić do rozwiązania trwającego od lat konfliktu. Kooperacja w tej dziedzinie przyczyniłaby się do budowy obopólnego zaufania, i zjednoczenia skonfliktowanych społeczeństw.

\section{Spory o wodę na terenie Azji}

Kolejnym mocno zagrożonym wybuchem konfliktu zbrojnego o wodę rejonem jest dorzecze Tygrysu i Eufratu. Ten wielki system rzeczny, obejmujący terytoria zamieszkane przez różne, często wrogo do siebie nastawione grupy etniczne, jest szczególnie ważny dla Syrii, Iraku i Turcji, w której obie rzeki mają swój początek. Wszystkie trzy państwa w ostatnich dziesięcioleciach prowadziły niezależną politykę i gospodarkę wodną, unikając jakichkolwiek ustaleń na forum międzypaństwowym (http://www.newsweek.pl/swiat/ wojny-o-wode-gdzie-moga-wybuchnac-konflikty-o-wode-,artykuly,362188,1.html). W rezultacie tego niejednokrotnie dochodziło do napięć we wzajemnych stosunkach. Przykładowo w 1975 r., w związku z wybudowaniem przez Syrię zapory Tabqa (późniejsza ath-Thawrah) na Eufracie, nastąpił kryzys dyplomatyczny w stosunkach z Irakiem przejawiający się m.in. wzajemnym odwołaniem attaché wojskowych oraz zamknięciem

\footnotetext{
13 września 1993 r. Premier Izraela Icchak Rabin oraz przywódca Organizacji Wyzwolenia Palestyny Jaser Arafat podpisali na trawniku przed Białym Domem porozumienie (tzw. Oslo I), będące efektem kilkumiesięcznych tajnych negocjacji prowadzonych w Norwegii przez obie strony konfliktu.
} 
przestrzeni powietrznej (Piotrowski, 2005). Kryzys ten utrzymywał się do lat 90. XX w., kiedy to oba kraje stanęły w obliczu jeszcze większego zagrożenia - na początku 1990 r. Turcja postanowiła całkowicie zamknąć tamę Ataturk na rzece Eufrat, pokazując w ten sposób, iż nie liczy się ze zdaniem swoich sąsiadów (Klare, 2002).

Niestety, każdego roku zaostrza się sytuacja na omawianym terytorium, wraz z kolejnymi budowanymi tamami. Turcja, nie zważając na interesy Iraku i Syrii, jest zdeterminowana realizować swoje własne projekty irygacyjne, które według prognoz mogą doprowadzić do uszczuplenia dopływu wód Tygrysu i Eufratu do sąsiadów Turcji nawet o 1/3. Czynnikami wpływającymi na rozwój wrogich nastrojów w tym regionie jest nawarstwianie się innych problemów, które od wielu lat utrudniają wzajemne stosunki (Klare, 2002).

Nie lepiej wygląda sytuacja w zakresie podziału wody w Azji Środkowej. Uzbekistan otwarcie grozi Tadżykistanowi rozpoczęciem wojny, jeśli Duszanbe zbuduje elektrownię wodną „Roguńska” na rzece Wachsz - dopływu Amu-darii, i ograniczy spływ wody. Problem ten co prawda nie pojawił się teraz, jednak dawniej udawało się łagodzić go za pomocą politycznych środków. Główny problem polega na tym, że w czasach ZSRR stosunki między państwami z nadmiarem i niedoborem wody w Azji Środkowej były regulowane przez Moskwę, stąd istniała tu pewna równowaga, pozwalająca państwom leżącym w górnym biegu rzeki na budowanie hydroelektrowni, a państwom położonym w jej dolnym brzegu - nie obawiać się niedoboru wody. Obecnie sąsiadujące ze sobą kraje nie potrafią zażegnać problemów spowodowanych przez deficyt zasobów wodnych nawet za pomocą środków politycznych. Zwłaszcza, gdy państwo położone w górnym biegu rzeki, buduje sztuczne zbiorniki wodne i przywłaszcza sobie część tych zasobów (Kowalenko, 2016; Kałmykowa 2016).

Woda może zostać także celem ataków terrorystycznych. Tego typu terroryzm, zwany terroryzmem środowiskowym (ekologicznym) wykorzystuje zasoby naturalne danego państwa, jako cele swojego ataku, który ma pozbawić konkretne społeczeństwo dostępu do danego zasobu. Jego celem, poza atakiem na potencjał środowiskowy danego państwa, jest również wywarcie określonej społecznej presji. Osiągany dzięki temu efekt psychologiczny sprawia, że tego typu działania nie uwzględniają żadnej formy eksterytorialności, zarówno cywilów, jak i środowiska naturalnego. Wyróżnić możemy dwa rodzaje tej formy „walki”: terroryzm wykorzystujący środowisko jako narzędzie oraz atak w jego zasoby. Pierwsza pojawia się wtedy, kiedy terroryści wykorzystują środowisko naturalne do bezpośredniego uderzenia w ludność cywilną (np. wysadzenie tamy rzecznej, co w konsekwencji powoduje zatopienie terenów miejskich). Drugi pojawia się w momencie, w którym to bezpośrednim celem jest środowisko, a ludność cierpi pośrednio (np. wprowadzenie toksyn do źródeł zaopatrujących społeczeństwo w wodę) (Pawłowski, 2005).

\section{Podsumowanie}

Zasoby wody pitnej są jednymi z najbardziej wrażliwych punktów, mogących być celami ataków terrorystycznych. „Atrakcyjność” zbiorników wodnych objawia się tym, że woda nie posiada żadnych substytutów. Natomiast jej nadmiar, tj. wywołanie powodzi poprzez wysadzenie tamy, może prowadzić do zatopienia ośrodków wojskowych czy przemysłowych.

Opinie dotyczące roli, jaką w przyszłych konfliktach międzynarodowych odegra woda, są zróżnicowane. Specjaliści przewidują zwiększanie się liczby tego typu konfliktów, i zapowiadają, że w najbliższych latach bezpieczeństwo wodne traktowane będzie na równi z bezpieczeństwem militarnym poszczególnych państw (Starr, 1991). Z drugiej strony niektórzy analitycy prognozują, iż główną przyczyną konfliktów zbrojnych w pierwszej połowie XXI w. nadal będą ropa i surowce mineralne (Selby, 2005).

Według prognoz naukowców, za 50 lat zapasy wody pitnej na świecie zmniejszą się o jedną trzecią, a może nawet o połowę. Są to nie tylko skutki zmian klimatu na Ziemi, lecz również nieracjonalne, a często wręcz bezmyślne wykorzystywanie zasobów wodnych. Nie ulega wątpliwości, że problem przewidywanych konfliktów o wodę nabiera współcześnie coraz większego znaczenia. Woda, będąca najważniejszym składnikiem życia i nie posiadająca żadnych substytutów, powinna być otoczona zarówno przez społeczeństwo, jak i przez forum międzynarodowe szczególną uwagą. Problemem są kraje, w polityce których nie ma miejsca dla problemów hydrologicznych (np. budowy kanalizacji czy oczyszczalni ścieków). Dlatego niezmiernie istotne są wspólne działania, które pozwolą zorganizować pomoc dla biedniejszych państw i przeznaczyć ją na rozwinięcie ich infrastruktury hydrotechnicznej. Jeśli bowiem ludzie nie zmienią swego podejścia do omawianego problemu, konfliktów zbrojnych z powodu wody na pewno nie da się uniknąćs

\footnotetext{
Chronologicznego uporządkowania konfliktów ściśle związanych $\mathrm{z}$ wodą, podjął się Pacific Institute for Studies in Development, Environment and Security, sięgając od 3000 roku p.n.e. do 2015 roku - zob. http://www2.worldwater.org/conflict/list/
} 


\section{Literatura:}

1. Borek, P. (2014). Angola (1960-2002) - od dekolonizacji do krwawej wojny o surowce. W: P. Kwiatkiewicz, R. Szczerbowski (red.), Europejski wymiar bezpieczeństwa energetycznego a ochrona środowiska: bezpieczeństwo-edukacja-gospodarka-ochrona środowiska-polityka-prawo-technologie (s. 901-914). Poznań: Fundacja na rzecz czystej energii.

2. From Scarcity to Security: Averting a Water Crisis in the Middle East and North Africa (1995). Washington DC: World Bank

3. Gleick, P. (1993). Water nad Conflict: Fresh Water Resources and International Security, International Security, 1, 71-112.

4. Hoffman, A. (2016). The Connection: Water and Energy Security. Pobrane z: www.iags.org.

5. http://www.national-geographic.pl/ludzie/wojny-o-wode

6. http://www.newsweek.pl/swiat/wojny-o-wode-gdzie-moga-wybuchnac-konflikty-o-wode-,artykuly,362188,1.html.

7. http://www2.worldwater.org/conflict/list/.

8. Jokiel, P. (2016). ,Mokre” konflikty. Pobrane z: www.hydro.geo.uni.lodz.pl

9. Kałmykowa, S. (2016). Przyszłość ludzkości: wojny o wodę. Pobrane z: www.polish.ruvr.ru

10. Klare, M.T. (2002). Resource Wars: The New Landscapes of Global Conflict. New York.

11. Kowalenko, N. (2016). Deficyt wody wysuwa się na pierwszy plan. Pobrane z: polish.ruvr.ru

12. Lipowska-Hamdy, M. (2016). Konflikty etniczne czy walka o wodę? Spory dotyczqce rzek na Bliskim Wschodzie i w Afryce Północnej. Pobrane z: www.woda.edu.pl

13. Lipowska-Hamdy, M. (2016). Niewidoczne oblicze konfliktu. Izraelsko-palestyńskie sporyo wodę. Pobrane z: www.woda.edu.pl

14. Lipowska-Hamdy, M. (2016). Skąd się biorq wojny o wodę? Pobrane z: www.woda.edu.pl

15. Pawłowski, M. (2016). Woda jako źródło życia i konfliktów zbrojnych. Pobrane z: www.politykaglobalna.pl

16. Piotrowski, M.A. (2005). Woda a geopolityka i bezpieczeństwo Bliskiego Wschodu. Sprawy Międzynarodowe, 2, 86-102.

17. Pronińska, K. (2005). Konflikty surowcowe we współczesnych stosunkach międzynarodowych. Sprawy Międzynarodowe, 3, 30-47.

18. Rękawek, B. (2016). Rozgrywki o wodę $w$ dorzeczu Jordanu. Pobrane z: www.stosunki.pl

19. Selby, J. (2005). Oil and Water: The Contrasting Anatomies of Resource Conflicts. Government and Opposition, 40(2), 200-224. https://doi.org/10.1111/j.1477-7053.2005.00150.x

20. Starr, J. (1991). Water Wars. Foreign Policy, 82, 17-36. https://doi.org/10.2307/1148639

21. Williams, P. (2002). Nile co-operation through hydro-realpolitik? Third World Quarterly, 6, 1189-1196. https://doi.org/10.1080/0143659022000036577 